\title{
Gendering the Copperbelt
}

\section{Introduction}

Although the lived experiences of women have commonly been marginalised in Copperbelt studies, gender dynamics have long been understood to be at the centre of Copperbelt society. The imposition of a gendered division of work on their employees was central to mine company profitability and to the (re)production of labour on both a daily and long-term basis. The focus in early literature on male 'migrant' workers distracted from the fact that women were both present and economically active in Copperbelt towns, but the terms of their presence varied significantly over time and between the two territories. Authorities - mine companies, colonial states and their intellectual advisors - debated whether mineworkers' wives and families should stay in the village or move to the town. The positions they adopted towards women's residence, labour and fertility rested on patriarchal assumptions about the changing nature of male and female labour and on the notions of 'African tradition' and 'Western modernity' that were central to knowledge production about the Copperbelt.

In this context, the Copperbelt induced moral panic about the supposed breakdown of 'traditional' norms, where prostitution and 'urban wives' were undermining African tradition or the modern Christian family (or both) and where juveniles lacked adequate socialisation as a result. Mine companies wanted women to be housewives, but were uncertain if they were up to the task. Alongside their core business of mineral extraction, these companies engaged in the systematic production of housewives and nuclear families. Young women were taught by company propaganda, training courses and social welfare officers how to raise children, clean houses and keep their husbands happy and productive. This chapter explores the extraordinary degree of this intervention, locates it in the perpetual effort to 
manage gender (and, to some extent, generational) relations in the city and demonstrates that it reflected a perennial anxiety regarding the ability of Africans, and African women in particular, to transition to an idealised form of urban society.

From the 1970s, however, feminist labour researchers identified the historical importance of the wives of Northern Rhodesian/ Zambian mineworkers in industrial action in the 1950s and 1960s and, indirectly, in political and economic change. Social historians in Haut-Katanga focussed, in contrast, on the ways in which women's position as housewives and mothers reflected the centrality of natalist policies in Belgian Congo and post-colonial Zaire. This distinction in the production of knowledge about urban mine women reflected differences in the history of labour and company policies but also in the perception of what constituted women's work. The intellectual separation of analyses of domesticity and workplace neglected the fact that women's economic position, bound up with their secondary status as 'mineworkers' wives', was shaped by their husband's salary, their domestic labour and the considerable work they did to earn money and produce food for the household. The vast majority of Copperbelt women went about the business of urban work unnoticed: largely excluded from the mine itself, women kept house and raised families, farmed, traded and made and sold goods.

The chapter concludes with an analysis of the changing nature of post-colonial social welfare. Ferguson was struck in the late 1980s by the continued existence of company-run women's centres on the Zambian Copperbelt. ${ }^{1}$ In Haut-Katanga, likewise, an elaborate system of social welfare intervention in family disputes, child rearing and the education and socialisation of young women continued to be provided by Gécamines and other companies until the 1990s (and still continues in diminished form today). Drawing on interviews with former company social welfare officers in both regions, continuity and change in the assumptions underlying these services is analysed: while the late colonial problem of urban modernisation had largely disappeared, support for the role of the mine company in shaping the family has if anything grown following the post-privatisation closure of mine social services.

1 Ferguson, Expectations of Modernity, p. 167. 


\section{Men and Women on the Interwar Copperbelt}

Early African migration to mine towns, essentialised as men's wage work, depended on agricultural and reproductive labour performed by women, who officially remained in rural areas. Male migration prompted anxiety, particularly among missionaries, about the loss of male labour from rural areas but also its (assumed) negative impact on family life. As noted in Chapter 1, UMHK efforts to secure African labour led in the 1920s to the extension of mineworkers' contracts. This became, from 1928, a self-conscious programme of stabilisation, incentivising mineworkers to bring their wives and children to the mine, in the belief that married workers would not only stay longer and be more productive but also be more socially 'stable', with domesticity limiting tendencies towards violence or political action. This dovetailed with the Belgian colonial belief that African birthrates were worryingly low, the result of a toxic combination of 'primitive' customs such as polygamy and modern urban ills including alcoholism. $^{2}$ This fuelled a co-ordinated natalist intervention towards the bodies and minds of young women. ${ }^{3}$ For its part, UMHK advanced 'bridewealth' payments to facilitate rural marriage for their workers, with the assistance of local colonial officials and the Catholic Church in general and de Hemptinne's Benedictine mission in particular. ${ }^{4}$ While the late colonial state substantially increased provision of developmental and welfare services across Belgian Congo, companies such as UMHK retained responsibility for delivering housing and social services to their workforce and their families.

The aim of improved productivity thus rested on essentialised gendered notions and - from the 1940s - the belief that industrial peace could be socially engineered by the production of appropriate family relations. Workers were provided with food rations and housing proportionate to family size. Health clinics, focussed on child and maternal care, were established. Women were compelled to give birth in company health facilities and to bring their infants for inoculations and periodic checks on their weight and general health. Non-compliance

2 Nancy Rose Hunt, A Nervous State: Violence, Remedies, and Reverie in Colonial Congo (Durham, NC: Duke University Press, 2016).

3 Hunt, 'La Bebe en Brousse'; Schalbroek, 'Commission for the Protection of Natives', p. 117.

4 Dibwe dia Mwembu, Histoires des Conditions de Vie, p. 17. 
could lead to the withholding of pay or rations. With church assistance, primary schools were established in every camp, free for the children of UMHK employees. Social centres ('foyers sociaux') were established that trained young women in keeping a respectable home as well as gendered skills such as sewing, knitting and cleaning. In the 1950s, Valérienne Ngoy Mudimbi taught the wives of senior African workers how to arrange their dining table for visitors and how their children should behave when eating. ${ }^{5}$ The interiors of mine houses and residential streets were regularly inspected for cleanliness, with prizes awarded for best-kept areas and sanctions for dirty and ill-kept homes. The company provided leisure centres and trained theatrical and musical groups that conveyed in their shows and songs moral lessons for family life (see Chapter 7). In these multiple and increasingly co-ordinated interventions into the domestic and recreational lives of their workers and their families, UMHK sought to both manage and increase their bodies' productive and reproductive value.

These sustained efforts certainly coincided with reduced labour turnover: the number of new recruits needed fell drastically from 6,582 in 1943 to 1,303 in 1958 . They also transformed the population of what were initially male-dominated mine camps. By the mid-1960s there were four women for every five men in UMHK townships and the proportion of both was dwarfed by the number of children - four on average for every woman - who made up 63.6 per cent of their populations. ${ }^{6}$ Housing and healthcare were steadily expanded at considerable cost to the company. The growing female population was also integrated into the UMHK system, not only as housewives but also as providers of foodstuffs from as early as the 1930s. As Dibwe dia Mwembu notes, women were 'incentivised' to grow vegetables by the threatened removal of their food ration and were forced to sell to the company at prices lower than those paid to European settler farmers: this then became part of the ration provided to workers. ${ }^{7}$

In Northern Rhodesia, however, legal restrictions on urban settlement meant male mineworkers continued to be treated as temporary migrants until the 1940s. Just as many men were able in practice to remain permanently employed by moving from one town job to another,

5 Interview, Valérienne Ngoy Mudimbi, Likasi, 9 June 2018.

6 Dibwe dia Mwembu, Histoires des Conditions de Vie, pp. 15-18.

7 Dibwe dia Mwembu, Histoires des Conditions de Vie, p. 21. 
many women made their way to town and stayed there by evading urban controls. ${ }^{8}$ Chauncey demonstrates that, to attract recruits, women (and children) were, in the late 1930s, allowed to enter some Northern Rhodesian mine compounds. ${ }^{9}$ However, they lacked the social provision accorded to their counterparts in Haut-Katanga and many survived by a combination of precarious 'urban marriages', unregulated agricultural and trading activities, and prostitution. Missionaries characteristically worried about what was labelled 'serial wifehood': a chapter in the landmark study by Merle Davis, Modern Industry and the African, found it to be common: 'Detection is difficult, and location managers find it discreet, unless serious family trouble should develop, not to inquire too closely into the marital relationships of their wards' ${ }^{10}$ Parpart argues that women's presence in mine compounds was discreetly welcomed or at least tolerated by companies, but - because of opposition by government and 'native authorities' and because of their own desire to control costs - provision of services for families and women was piecemeal, reactive and ran well behind such provision in HautKatanga. ${ }^{11}$ Women (and men) nonetheless increasingly resided in Northern Rhodesian mine towns for longer periods in the 1930s and 1940s. While it is impossible to know what percentage of women migrated with their husbands, or met them in towns, it is certainly true that women made a substantial contribution to household income and reproduction by adapting their existing skills in brewing and farming to an urban setting. ${ }^{12}$

Chauncey was the first historian to identify the centrality of women's agricultural work for household reproduction: in Luanshya as early as 1935, 2,000 agricultural plots were allocated specifically to the wives of mineworkers, with some employing male workers on these plots. ${ }^{13}$ Township markets were established where women could sell farmed produce under company supervision and local Lamba farmer-traders

8 Ferguson, Expectations of Modernity, pp. 170-7.

9 George Chauncey Jr., 'The Locus of Reproduction: Women's Labour in the Zambian Copperbelt, 1927-1953', Journal of Southern African Studies 7, 2 (1981), pp. 135-64, p. 137.

10 Charles M. Coulter, 'The Sociological Problem', in John Merle Davis, Modern Industry and the African (London: Macmillan, 1933), cited in Parpart, 'The Household and the Mine Shaft', p. 40.

11 Parpart, 'The Household and the Mine Shaft', p. 41.

12 Chauncey, 'Locus of Reproduction', pp. 143-6.

13 Chauncey, 'Locus of Reproduction', p. 139-49. 
were excluded to facilitate this. Chauncey's interviewees in 1978 recalled successful African businesswomen who in the 1940s ran transport, restaurant and hotel services. ${ }^{14}$ However, as mine employment expanded in the late 1940s and 1950s, no attempt was made to expand the provision of agricultural plots across all mines and government officials looked at women's independent farming activities with suspicion:

a well defined characteristic of Copperbelt towns ... is the way Africans, especially the African women, go out and cultivate any bit of vacant land anywhere, without much regard for municipal regulations and certainly very little for its ownership. Air photographs show that cultivation covers from one to three thousand acres in and around each township.... It will take a very long time to wean the people of the desire to cultivate ... provision ... is needed in all the Copperbelt towns for some sort of outlet for peoples' energies in this direction. ${ }^{15}$

Despite the extraordinary scale and ubiquity of African Copperbelt agriculture (which is further discussed in Chapter 9), it was viewed by late colonial officials as a backward and essentially unhelpful activity. The fact that farming was mainly done by women served to demonstrate its backwardness. While commercial agriculture, for example, involved officially approved forestry and charcoal-burning initiatives, in Ndola in 1959

agriculture [was] no more than the sporadic planting of a few seeds, usually by women, whenever a patch of vacant land can be found. Both Rhokana Corporation and the Forestry Department have intensified patrols over the land bringing an increasing number of offenders before the Urban Native Court.... deputations of women from the Municipal Housing Areas [have been] told that it was not possible to reserve large gardening areas for them within easy reach of their houses. ${ }^{16}$

Some company officials desired a Katanga-style married and stabilised African labour force, but in Northern Rhodesia they had to reckon with the opposition of settler farmers and missionaries to

14 Chauncey, 'Locus of Reproduction', p. 153.

15 NAZ, WP 1/2/64, Special Commissioner for Western Province Reports on Copperbelt, 1959-60, Draft Report on Municipalities and Towns, n.d. but 1960.

16 NAZ, WP 1/2/64, Special Commissioner for Western Province Reports on Copperbelt, 1959-60, Annual Report, African Affairs, Ndola Urban, 1960. 
permanent stabilisation. African authorities equally sought to control and restrict women's mobility: recognised chiefs, mine-based 'tribal' elders/representatives and the African Representative Council, from its establishment in 1946, opposed women's migration, which, it believed, contributed to a moral crisis regarding marriage: 'Women ... find there will be no difficult $[\mathrm{y}]$ in the towns about getting married ... whom are they going to call, and who is going to receive the dowry? I have seen children who forget their parents and just think of the towns'. ${ }^{17}$ The high divorce rate was evidence for chiefs of the inauthenticity of urban marriages; bridewealth and other marriage customs were only loosely observed. ${ }^{18}$ The introduction of a pass system for women, in response to native authority demands, sought (unsuccessfully) to stem the flow of female migrants. In practice, companies issued passes to women who were vouched for by male workers and there was neither the capacity nor the stomach for checking women's registration documents.

The 1940 mineworkers' strike was, as already noted, a key event in persuading reluctant Northern Rhodesian company and government officials that stabilisation must now be embraced. With that came a belated investment in family housing and the social welfare systems pioneered north of the border. In contrast, the 1941 strike in HautKatanga was thought to have been caused by the poor conditions of mine camps: despite their far advanced development compared with those of Northern Rhodesia, officials still perceived them as places of disorganisation and promiscuity and there was, thereafter, a further expansion of family housing, services and surveillance. ${ }^{19}$

The underlying issue, for companies, the state and African elders, was effective control over women's productive and reproductive labour. When female settlement was officially accepted in the Northern Rhodesian mines in the late 1940s, it came - as it had in

17 NAZ, J. Sandasanda (Western), ARC II, 23 January 1951, quoted in Chauncey, 'Locus of Reproduction', p. 156.

18 Chauncey, 'Locus of Reproduction', p. 162. Male elders across mid-twentiethcentury sub-Saharan Africa warned of a growing moral crisis arising from women's urban migration: for East Africa, see Derek R. Peterson, Ethnic Patriotism and the East African Revival, c. 1935-1972 (Cambridge: Cambridge University Press, 2012). For southern Africa, see Teresa Barnes, 'The Fight for Control of African Women's Mobility in Colonial Zimbabwe, 1900-1939', Signs, 17 (1992), pp. 586-608.

19 Dibwe dia Mwembu, Histoire des Conditions de Vie, p. 27. 
Haut-Katanga - at a price: women in both regions were expected to fulfil a profoundly gendered role as housewife and mother. Their position in the mine township rested, officially at least, on their marriage to a man employed by the mines. ${ }^{20}$ They had no representation, to company or state officials, other than via their husbands. ${ }^{21}$ And they were expected by these officials and their social scientific advisers to play the leading role in creating and reproducing the modern urban nuclear family, which would be the foundation of a productive male workforce and the key to socialising future generations of urban youth.

\section{Gender in Social Scientific Research}

These gendered concerns were central to the efforts of the social scientific community in the 1940s and 1950s to produce applied knowledge about the new urban communities. In Katanga, CEPSI researchers such as Arthur Doucy not only worried about the capacity of families to make the transition to modernity, but - in line with the Institute's applied approach to social research - helped establish new social centres in the Elisabethville CEC to train them to do so. ${ }^{22}$ The CESPI researchers also assessed the colonial state's efforts to make customary law work in non-mine areas of Elisabethville in the early 1950s. While Vannes argued that '[c]ustom is certainly the form of law best suited to the rapid evolution of social and economic life in a CEC', he was, like rural chiefs, disparaging about its functioning in a city where there 'are rather a juxtaposition of particular customs; a shapeless mass whose imperatives collide without being able, very often, to integrate harmoniously with each other'. ${ }^{23}$ Although most people still married within their ethnic group, there were 'more and more young people in Elisabethville marrying people of diverse provenance', leading to confusion and conflict over which customs should apply to the resulting 'mulatto' family. For example, 'it is commonly accepted that only the husband can lodge a complaint for adultery by his spouse: but what

20 Jane L. Parpart, 'Class and Gender on the Copperbelt: Women in Northern Rhodesian Copper Mining Communities 1926-1964', Boston University African Studies Working Papers, 77 (1983). See also Parpart, 'The Household and the Mine Shaft', pp. 36-56.

21 Dibwe dia Mwembu, Histoire des Conditions de Vie, p. 26.

22 Rubbers and Poncelet, 'Sociologie Coloniale au Congo Belge', p. 98.

23 J. Vannes, 'De L'Evolution de la Coutume d'Elisabethville', CEPSI Bulletin, 32 (1956), pp. 223-68, p. 227. 
if the wife belongs to a [ethnic] group that does not repress this offense? ${ }^{24}$ Vannes found that married women, while lacking ownership rights to property and businesses that had to be in their husbands' names, were nonetheless funding house construction and ordering supplies for their businesses, and revealed that courts were awarding compensation to divorced women for property they had financed but didn't legally own. An attempt to ban the 'evil' of polygamy in town in April 1950 meant that all second marriages were null and void. Because polygamy was itself treated as a crime, wives in customary second marriages had no legal protection whatsoever.

Reflecting the general focus of research on formally employed male workers and their organisations and associations, women were rarely the direct subject of analysis. Epstein noted that during the 1952 mineworkers' strike, '[e]ach day the strikers and their womenfolk would go off en masse to cultivate their gardens'. He didn't, however, investigate the significance of this farming for household reproduction. ${ }^{25}$ Schumaker notes that attempts by RLI researchers to recruit African women to conduct research were adversely affected by their husbands' unwillingness to allow them to conduct urban fieldwork. ${ }^{26}$ As Ferguson notes, many Copperbelt residents were themselves heavily invested in activities associated with respectable family life, but it is also clear that the instances of performative 'civilised' behaviour in leisure and courtship highlighted by researchers - for example, the purchase of tailored Western-style clothes and leisure activities such as ballroom dancing reflected their disproportionate focus on the African elite. ${ }^{27}$ Epstein noted, however, that, contrary to the projections of the most optimistic observers, actually existing mine households were not occupied by discreet nuclear families but rather by 'a unit that was immediately tied into a wider set of kinship ties and obligations'. ${ }^{28}$ All the evidence suggests that Copperbelt residents both in and outside the mine areas continued to live in flexible family structures that were far from any nuclear norm: houses built for the envisaged nuclear families were consistently overcrowded with visiting rural relatives in search of

24 Vannes, 'De L'Evolution de la Coutume', p. 231.

25 Epstein, Politics in an Urban African Community, p. 96.

26 Schumaker, Africanizing Anthropology, pp. 210-1.

27 Ferguson, Expectations of Modernity, p. 175.

28 Epstein, Politics in an Urban African Community, p. 46, quoted in Ferguson, Expectations of Modernity, p. 173. 
employment and educational opportunities. As already noted, many migrants got jobs in town by initially staying with established family members, breaching the terms of the latter's leases leases in both mine and non-mine areas. As Ferguson argues, the apparent disjuncture between nuclear family ideals and the reality of such familial circumstances was resolved by RLI observers with the assumption that a 'trend' towards stabilisation was underway, the transitional phase emphasised by Epstein and many other researchers. ${ }^{29}$

Powdermaker's study of late colonial Luanshya, conducted in 1952-3, stands out for its privileging of African voices in general, and women's voices in particular, in their (and her) efforts to make sense of the social change unfolding around them. ${ }^{30}$ Powdermaker, influenced by but operating separately from the RLI, observed considerable tension and instability in marital relationships. She found that

the picture of family life and marriage on the mine township was ambiguous and complicated. Some traditional attitudes towards marriage, sexual relations, and the family persisted, a few in exaggerated form; others were in conflict with new attitudes; and there were many patterns of compromise. ${ }^{31}$

African marriage, Powdermaker explained, had been a contract between kindred groups, based on 'bride price', with polygamy aspired to by all men but achieved only by those of high status. Adultery was common and divorce 'an essential liberty'. ${ }^{32}$ In town, conflict arose over the husband's willingness to transfer part of his wages to his wife to spend on the necessities of urban sustenance that could only be acquired by purchasing goods for cash. In the mine towns, polygamy was difficult in family homes designed along monogamous, nuclear lines, while innovative 'inter-tribal' marriages brought new problems. There was a strong aspiration, amid much instability and conflict, to an individual family with a life partner of one's choice, at least 'among the intelligentsia and middle class'. ${ }^{33}$ Powdermaker provides extended first-person narratives of courtship, betrothal and marriage: conflicts arose between the costs of urban family life and male workers' obligations to support their rural kin in increasingly monetary terms. Divorce and remarriage were common. Powdermaker captures an exceptionally

29 Ferguson, Expectations of Modernity, pp. 172-4.

30 Powdermaker, Copper Town. 31 Powdermaker, Copper Town, p. 151.

32 Powdermaker, Copper Town, pp. 32-6.

33 Powdermaker, Copper Town, p. 152. 
detailed picture of gendered relationships, but her work contains equally striking absences. She asserts, along with some of our interviewees, that women preferred town life because they did not have to work so hard, but her account of a typical woman's life does not include agricultural or trading activities. ${ }^{34}$ While she is clear that most urban marriages were unstable hybrids of custom and modernity, she assumes this reflected the transition supposedly underway from one type of marriage - kinship-based, polygamous and rooted in 'superstitious' teachings about fertility - to another - nuclear, monogamous and based on a clear division between male breadwinners and female housewives.

\section{Late Colonial Social Welfare: Making the Urban Family}

The policy of stabilisation in Northern Rhodesian mine towns reflected belated recognition by the colonial authorities that marriages were being made in town outside customary authority and therefore needed to be subject to 'modern' regulation. In 1953, for example, despite opposition from African authorities, Urban Native Courts were authorised to issue marriage certificates without Native Authority permission. ${ }^{35}$ Alongside this, the rapid expansion of social services was a response to the marital tensions that resulted from the failure of urban employment to provide families with the life to which they aspired. As Parpart notes, company provision of marital counselling and courses in household economics was attractive to women, who regularly sought intervention by social case workers. Maintaining one's marriage, rather than opting for divorce, became a more attractive option when men were provided not only with wages but also housing and social benefits for their families. ${ }^{36}$

The late colonial period saw, as elsewhere in British-ruled Africa, a considerable expansion in state-directed welfare provision. In the mine areas of Copperbelt towns, however, companies jealously guarded control over social provision and leisure opportunities for

34 Powdermaker, Copper Town, pp. 189-90. Our interviewee Fridah Mwale (Mufulira, 6 July 2018) recalled: 'The work in the village was very difficult. We had to do things such as drawing water, grinding millet and getting grass to thatch the huts but most of those things were not being done here'.

35 Chauncey, 'Locus of Reproduction', p. 163.

36 Parpart, 'The Household and the Mine Shaft', p. 53. 
their employees. ${ }^{37}$ New mine welfare departments were established, for example in Luanshya in $1952 .{ }^{38}$ The burgeoning social welfare community drew lessons from the expansion of state welfare in post-World War Two western Europe but also believed that local circumstances called for specific expertise. Conferences brought together government officers with responsibility for town planning, policing and social welfare, alongside sociologists and anthropologists. Participants asserted the centrality of urban life to Africa's future development, but worried about towns' ability to provide social security for the old, socialisation for the young and the reproduction of stable family life. Ostensibly technocratic discussions were underpinned by moralistic notions, for example the need to restrict urban residence to those in employment and their immediate families while excluding unemployed 'loafers' (see also Chapter 2).

While Northern Rhodesian companies' social services were less developed compared with Haut-Katanga, by 1954 the Northern Rhodesian Council for Social Services (NRCSS) was co-ordinating provision by churches, mine companies and European women's groups. ${ }^{39}$ Council members worried that the limited opportunities for education and jobs for juveniles would cause delinquency and social unrest. By the late 1950s, Northern Rhodesian mine companies were providing youth centres and sports training. Powdermaker provides a snapshot of the early development of Luanshya's services: headed by a male European welfare officer and composed of 'several [male] African assistants' and two European 'lady welfare officers', their expanding services included reading and writing rooms, 'literacy classes, day nurseries for preschool children; classes for women in cooking, sewing, knitting, nutrition, and infant care; girls' clubs; and other social and educational pursuits'. ${ }^{40}$ But the work involved was ever expanding and the gathering of knowledge vital:

37 For an instructive British colonial comparison, see Andreas Eckert, 'Regulating the Social: Social Security, Social Welfare and the State in Late Colonial Tanzania', Journal of African History, 45, 3 (2004), pp. 467-89. Hansen, 'After Copper Town', p. 442.

39 NAZ, MLSS 1/12/5, Northern Rhodesia Council of Social Services 1967-8 [incorrect dates], 'Northern Rhodesia Council of Social Services', 9 August 1954.

40 Powdermaker, Copper Town, pp. 106-7. 
Bewildering changes are taking place in the pattern of family life, in economic life and ideas about ... leisure ... it is of fundamental importance that the social worker be equipped to understand and estimate the situation. He must be able to know how to conduct a social survey in order to get all the true facts... Through the medium of sociological research he must know how to discover the FELT NEEDS of those with whom he has to work. ${ }^{41}$

A central area of concern and knowledge production was, as noted, African marriage customs and the ways in which they had changed - or would need to change - in town. At the 1961 NRCSS conference, a presentation on research by the Native Courts Department demonstrated that urban marriages were based on 'tribal practices' that were not in fact fixed but had been evolving steadily since the 1930s. Divorce cases dominated the work of such courts because 'in urban areas there is no one tribal custom and also, a large proportion of the unions are either inter-tribal marriages or mere concubinage'. ${ }^{42}$

It became increasingly clear that effective urban social welfare would require its own indigenised workforce: 'In any scheme the educated Africans must carry the message to their own people. They were essential co-workers' ${ }^{43}$ There was, however, a tension between, on the one hand, the need for such a cadre, representative of the advanced class of urbanised Africans and able to educate and socialise new urban residents and, on the other hand, the belief that urban migrants needed to be kept in touch with their rural or 'tribal' culture during transition, and that (unlike whites) advanced Africans had access to customary knowledge that they could deploy in a developmental way in town. The result of these rapid changes was to bring to the fore a new generation of African welfare officers in both mine and government employment, whose understanding of African advancement and development chimed in many respects with the Copperbelt's indigenous elites. This understanding was articulated in the address to the NRCSS 1960 conference by Steack Mwale, Northern Rhodesia's first African senior welfare officer. Mwale told the conference:

NAZ, MLSS 1/12/5, Northern Rhodesia Council of Social Services 1967-8 [incorrect dates], NRCSS Social Workers' Conference, 25 September 1958. Emphasis in original. Ibid, p. 12.

43 NAZ, MLSS 1/12/5, Northern Rhodesia Council of Social Services 1967-8 [incorrect dates], NRCSS Social Workers' Conference, 25 September 1958, Doctor Donnolly, Medical Officer of Health, Lusaka Municipality. 
African society before the advent of the white man ... was a self-contained and self-sufficient tribal pattern of life. ... [which] depended largely on kinship ties ... [in] communities [with] a somewhat static social order. [A] sense of belonging kept people observing community standards of conduct and behaviour.... The impact of western culture with its ... dynamic social order ... has brought to the African a transitional period in which he is experiencing revolutionary social changes, giving rise to the need for social services. ${ }^{44}$

Mwale criticised the failure of European social welfare providers to engage with African elites, which meant Africans perceived social services 'as foreign and unwanted'. ${ }^{45}$ Africans, he argued, needed to be given opportunities for 'active participation' via 'popular and natural leaders of their own choice'. The transition to a sustainable urban social order would, it was clear, require African political leadership at the highest level. It would also require what were initially termed female African 'welfare assistants': most potential female recruits lacked the formal education necessary to qualify as social workers, but Lusaka's new Oppenheimer College of Social Services would, from 1961, train an expanded cadre of professional African social workers.

The question of how to marry well in the city was, it should be stressed, one that concerned other African observers. A central theme of Namusiya in the Mines (see Chapter 1) is the baleful influence of prostitution, itself presented as an immoral imitation of European styles: 'Prostitutes have many ways of attracting men. They paint their lips and cheeks with red paint they see European women using, and sometimes use white powder on their faces.... Some of them also wear trousers or shorts. They copy every fashion they see European women adopting'. ${ }^{46}$ Namusiya is, however, saved from such temptations by a good marriage:

He wanted a suitable woman who was a Mwiila [his 'tribe']. Mixed marriages, he realised, led to all sorts of complications. Children born of such a marriage would belong to neither one tribe nor the other ... In the event of a divorce, who would look after the children? ... [but] he did not wish to marry a woman with whom he was not acquainted.... The folk at home may choose a woman who is quite unattractive to the man. ${ }^{47}$

44 NAZ, MLSS 1/12/7, N R Council of Social Services, 1960-2, Report on 1960 Annual Conference.

45 Ibid., p. 5. ${ }^{46}$ Kaavu, Namusiya at the Mines, p. $54 .{ }^{47}$ Ibid. 
Namusiya ultimately finds a bride who is of his tribe, recently arrived in the mine compound, who he marries in church and not according to village customs.

In real life, Copperbelt residents, like Namusiya, searched for knowledge on how to make successful relationships and reconcile rural custom with urban life. This search, particularly for the region's growing literate elite, led them to newspapers in general and their advice columns in particular. Kallmann's analysis of these publications in late colonial Zambia argues that they projected a universally desirable model of urban African womanhood, that was, however, drawn from the experiences of a tiny group of privileged women who served, like indigenous elites in general, as an ideal to which to aspire for all African women. ${ }^{48} \mathrm{~A}$ particularly valued source was 'Josephine', a wise African woman whose column in the Central African Mail provided advice to those 'men and women ... [who] are having to adjust to sudden changes of outlook and custom'. ${ }^{49}$ Two typical letters read:

I work underground in the mine with no chance of returning home to get married, so for the present I have a half-wife here. She is not of my tribe ... but she tells me she loves me ... In fact I love her too. Shall I marry her, or wait a year or two til I go home and get a tribe-wife $?^{50}$

I am from Barotseland and the girl of my choice is not. I wrote to my parents trying to explain but they say I must leave the girl alone. They say, We have found a girl for you to marry - just send your picture and the money for 'lobola' [bride price]. I was in town soon after birth, educated in town and have never visited my tribal home, so know nothing of it. Can I have a girl without my parents' consent, or must I obey and send money and picture for a girl? ${ }^{51}$

It is noteworthy that 'Josephine' was herself not the stylish African woman depicted in the column photo, but in fact Barbara Hall, the British-born wife of the newspaper's editor. In his introduction to the edited collection of these letters, published months before Zambian independence in 1964, soon-to-be President Kenneth Kaunda expressed his hopes and fears about social change:

48 Deborah Kallman, 'Projected Moralities, Engaged Anxieties', pp. 71-117.

49 Barbara Hall (ed.), Tell Me Josephine (London: Andre Deutsch, 1964), Frontispiece.

50 Hall, Tell Me Josephine, p. 68. 51 Hall, Tell Me Josephine, pp. 66-7. 
time will fuse together elements from our traditional African culture and values with the attitude and morality of Europe and other continents. Whether Africa will be able to take the best of the cultures of more 'advanced' countries, and resist the worst ... we must wait and see.... in times of breakneck change, the pressures are immense, especially on young people. Old values are falling away, and little that is solid exists to replace them. In such conditions of bewilderment, in crowded towns, young people can turn all too easily to delinquency and immorality. ... Not enough, I fear, is being done to examine the roots of the troubles and to suggest bold solutions. Most intensive research is needed, and the findings must be implemented swiftly. ${ }^{52}$

In Haut-Katanga, advice was provided by Mwana Shaba, UMHK's monthly newspaper for its workforce and their families. Mwana Shaba sought to project the image of an idealised mine family in posed photos of senior workers and their families. A regular advice column, 'Baraza ya Bibi' ('Women's Forum' in Kiswahili), explained in painstaking detail how to wash and sew clothes, clean homes and access childcare in the mine towns. While the gender values on display were similar to those in the contemporaneous West, they were underlain with a strong evolutionary characterisation of African society, alongside a projection of UMHK's all-seeing benevolence. A story encouraging the feeding of formula milk to children was headlined, 'Are you a good father to your family?' It explained that the cash supplement now paid to senior UMHK workers instead of rations (see Chapter 4) was equivalent to 'the amount that a UMHK worker, married and father of two children, receives for each day of work in order to feed his family'. This cash replacement was only provided in the first instance to more experienced workers since 'the Company knew that they would support their families. Weren't they used to living in the camps and managing their budget? This is not the case for many Congolese who do not know how to avoid unnecessary expenses or buy at the best price'. The company was, however, concerned that its trust was misplaced:

The Company has therefore shown its confidence in the best of its workers. Was it wrong to trust? Yes to a certain extent, since the doctors maintain that there are sick and weak inhabitants of our cités, because of lack of nutrition. ... Some workers may spend all their income on selfish 
amusements; it also happens that they drink beer in large quantities, without thinking of the abandoned and hungry family. ${ }^{53}$

Similar rhetoric infuses a 1958 story about alcoholism: 'Truly my friends, if some Congolese continue to drink like this, they will not be able to progress and sooner or later they will disappear like the millions of American Indians who drank the fire water ... that killed them all'. ${ }^{54}$ In a series of articles in late 1958 and early 1959, Mwana Shaba devoted extensive attention to the question of African urban marriage (far more than to the political upheaval that would soon bring about independence). These articles drew on the correspondence of readers, not only on the ideal marriage but also the social problems associated with it in the new urban milieu. Wives were enjoined:

Do not let your husband dress in a badly patched shirt or trousers with holes because it is you who will bear the mockery of his friends.... Do not spend more money than your husband earns and especially never blame him for earning too little. On the contrary, encourage him to progress in his profession to improve his situation, give him confidence in his abilities, be proud of him and try to justify this pride. ${ }^{55}$

Husbands were instructed not to treat their wives as slaves or possessions but as companions and to avoid infidelity, alcoholism and 'unjustified jealousy'. 56 Marriages between those of mixed 'tribal' origins created problems, in particular for children of divorced parents because of their family's differing customs. ${ }^{57}$ Mwana Shaba was particularly scathing about the commercialisation of the dowry:

the objects [previously] given as dowry have been replaced bit by bit with money ... this way of falsifying the customary conception of the dowry has made it possible to believe, wrongly, that the delivery of dowry could be akin to a purchase. ... Some parents ... must curb their thirst for money and stop selling their daughters like goats. ${ }^{58}$

55

Belgian BAA, Mwana Shaba, No. 5, May 1957, 'Etes-Vous Bons Peres de Famille?'

BAA, Mwana Shaba, No. 3, March 1957, 'Alcoholism: the Mortal Enemy of the Congolese'.

BAA, Mwana Shaba, No. 6, June 1958, 'Pour un Foyer Heureux'.

BAA, Mwana Shaba, No. 5, May 1959, 'Du Mariage'.

BAA, Mwana Shaba, No. 7, July 1959, 'Du Mariage'.

BAA, Mwana Shaba, No. 3, March 1959, 'Du Mariage'. 
Polygamy was equally criticised by the newspapers' writers but, like social scientists such as Powdermaker, Mwana Shaba's editorial line was that it would not be an enduring problem: 'we will not speak of it, since polygamy tends gradually to disappear with the advancement of Congolese society and because only monogamous marriage finds help and protection in the law, ${ }^{59}$

For their part, Mwana Shaba's readers, whose letters increasingly featured in its pages, both shared and dissented from the newspaper's projection of a confident modern future in which 'backward' customs would wither away. Alongside a confidence in the capacity of modern institutions and instruction to facilitate progressive social change was a characteristic anxiety about what was being lost in this transition. In January 1959 Mwana Shaba quoted at length the views of reader M. A. Kabunda regarding the transmission of customary knowledge about family life:

We learned from the mouths of our grandparents their customs without having seen them.... If our ancestors did not know civilization, they were nevertheless wiser than us for certain things. They led a peaceful life in their household: the wife was subject to the husband, the husband liked her and good relations prevailed between the spouses.... Therefore there were not as many divorces as today.... I ask the young people who read me to return to the teaching of our ancestors so that they can live without great difficulty. ${ }^{60}$

The desire to both modernise urban family life and to adhere to custom in some altered form was, then, not simply a late colonial construct: it was articulated by many members of Copperbelt society. Far from being a transitory moment between one stable familial order and a new one, the enduring tumult of the urban social order would continue to make itself felt in the post-colonial Copperbelt.

\section{Women as Workers, Women as Wives: Gender in Copperbelt Social History}

In the 1970s and 1980s a generation of social historians turned to the study of what was by then the recent history of the late colonial Copperbelt family, influenced by the rise of women's history and keen to write gender and the private sphere into a Copperbelt literature

59 BAA, Mwana Shaba, No. 2, February 1959, 'Au Mariage'.

60 BAA, Mwana Shaba, No. 1, January 1959, 'Au Mariage’. 
hitherto dominated by mining, men and work. They, like social historians everywhere, were challenged by the absence of women's voices in the official record and read against the grain of that invisibility while also gathering oral histories of the women concerned. ${ }^{61}$ The foci of this research, however, took strikingly distinct forms in the two Copperbelt regions, reflecting both their own social history but also how identity and knowledge about it had previously been constructed.

In the Zambian Copperbelt, where a social identity rooted in politicised organised labour had been established (Chapter 4), historians studied women as economically and politically significant labourers in mine communities. Chauncey, for example, showed that women's labour was central not only to childrearing but to 'daily reproduction of labour power, that is, the daily maintenance of the worker'. ${ }^{62}$ Karen Tranberg Hansen identified the failure of officials to recognise domestic labour as work: 'When colonial authorities complained that urban African women were idle and lazy, they failed to recognize the timeconsuming tasks of food processing and preparation and the constant demands that children and their care placed on women'. ${ }^{63}$

The most important historian of the late colonial Zambian Copperbelt, Jane Parpart, built on Epstein and Powdermaker's research to show how strikes and protests in the 1950s were community events, playing out as much in the township as in the mine itself and influenced by the grievances of both women and men. ${ }^{64}$ This was still the case at the time Parpart was researching and writing: postindependence union meetings remained public events held in mine townships and attended by entire families. Women questioned and criticised union leaders for their alleged failure to meet their financial needs via wage increases for their husbands. ${ }^{65} \mathrm{My}$ own research shows that women took their protests over, for example, health provision directly to company officials, who refused to meet them 'because the company does not recognise dependants as representing employees on

61 Among a rich literature see, for example, Sherna Berger Gluck and Daphne Patai (eds.), Women's Words: The Feminist Practice of Oral History (New York: Routledge, 1991).

62 Chauncey, 'The Locus of Reproduction'.

63 Karen Tranberg Hansen, 'Body Politics: Sexuality, Gender, and Domestic Service in Zambia', Journal of Women's History 2, 1 (1990), pp. 120-42.

64 Parpart, Labour and Capital; Parpart, 'The Household and the Mineshaft'.

65 Larmer, Mineworkers in Zambia, pp. 112-3. 
any matters' ${ }^{66}$ This lack of direct representation paradoxically made it easier for women to demonstrate their discontents without fear of reprisal. As one of the mineworkers' union's first female branch officials explained: 'that woman is not recognised by the Company. ... Even if they're to cry out, Management would not look at them, because they don't know them. When you fight, nobody will apprehend you'. ${ }^{67}$ This was clearly demonstrated during protests over food shortages in July 1981 (Figure 5.1), when mineworkers' wives wearing their husbands' overalls and hard hats mounted pickets to prevent their husbands working. ${ }^{68}$ While the Times of Zambia warned mineworkers to resist 'petticoat incitement' to strike action, some male mineworkers themselves reportedly donned dresses, headscarves and false breasts to disguise their presence in female-dominated pickets that physically attacked employees who sought to work. ${ }^{69}$

A quite different dynamic can be seen in parallel studies of the role and participation of women in Haut-Katanga's mine towns. From the 1970s, the social scientific study of urban Haut-Katanga at the University of Lubumbashi (see Chapter 6) focussed not on workerist or class dynamics but rather on familial and gender relations. Donatien Dibwe dia Mwembu, in historicising the development of the UMHK/ Gécamines ideal family, showed that women used their subordinate role as company wives to secure and advance their socio-economic position in town. From the 1950s until the 1980s, the extensive social wage provided to the workers and families of Gécamines (and to some extent other companies such as SNCC/Z, the state-owned railways) meant that some women could live a comparatively secure life as housewives and mothers without needing additional earnings. This position, however, rested on their fulfilment of a different kind of work, their participation in the childcare and reproductive systems established by the company. Gécamines continued the natalist policies

66 Mineworkers' Union of Zambia (hereafter MUZ), Luanshya, 'Meetings with Management, 1975-78', Asst Personnel Superintendent, MUZ Officials, and Women Representatives of Demonstrators, 15 March 1978.

67 Interview, Rodah Matoba, Luanshya, 21 January 2003, quoted in Larmer, Mineworkers in Zambia, p. 114.

68 Times of Zambia (hereafter ToZ), 1 July 1981.

69 Interview, George Mukoma, Chiliabombwe, 11 February 2003, quoted in Miles Larmer, 'Zambia's mineworkers and political change, 1964-1991', unpublished PhD thesis, University of Sheffield (2004), p. 205. 


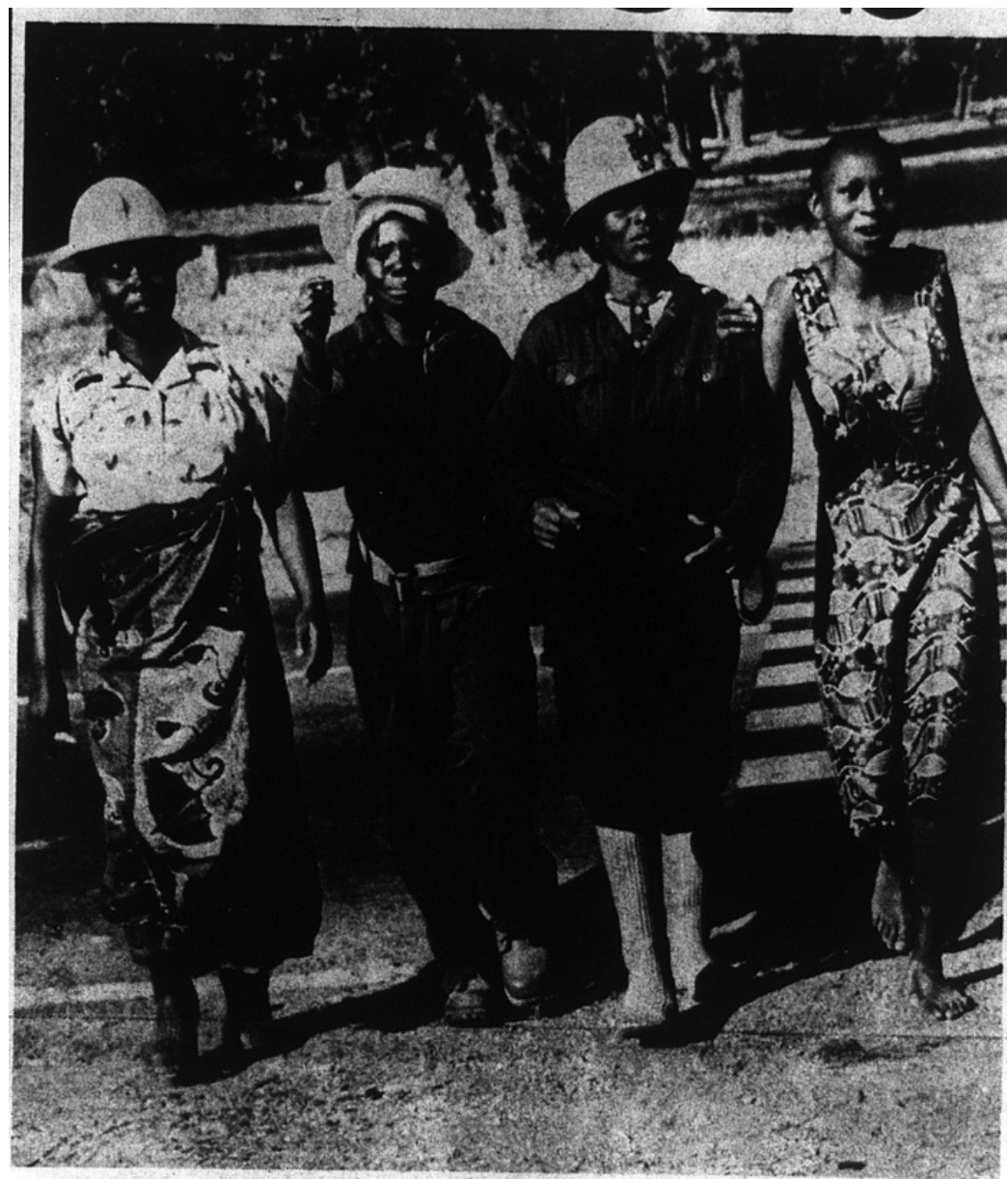

- MINERS' wives [from left] Mrs Mary Slame, Mrs Jane Chisanga, Mrs Beletina Mwaba and Mrs Chimwemwe Mufunl march to No. 3 shaft.

Figure 5.1 Protesting wives of mineworkers. Times of Zambia, 7 July 1981. Picture courtesy of the Times of Zambia.

pioneered by UMHK, obliging women to give birth in hospital and to bring children in for regular health checks. ${ }^{70}$

Despite this maternal labour, mineworkers' wives, like their Zambian counterparts, lacked direct representation with the company that dominated their lives: as Dibwe dia Mwembu puts it, 'The husband is the

70 Interview, Agnès Njamba, Likasi, 16 July 2019. 
representative of the company in his family.... While the man works, the woman, excluded from the modern world of work, takes care of the household'. ${ }^{71}$ Wives needed to obtain their husbands' assent to open a bank account, obtain a trading licence and - in relation to the company's maternal services - to have themselves sterilised. In HautKatanga, however, this exclusion does not appear to have prompted outright challenge of the sort witnessed in Zambia. Indeed, wives were kept subjugated by the privileged position of their husbands: 'fidelity and submission by women to their husbands was the condition sine qua non to avoid being rejected and replaced by the numerous women who were waiting in the cité ${ }^{72}$ The ability of salaried husbands to pick and choose their wives was emphasised in popular culture: Dibwe dia Mwembu cites the song 'Balimwatsh' by the Kolwezi-based group L'Orchestre Safari Nkoyi about a covetous woman who was unsatisfied with the salary her husband brought home at the end of the month and who, because of her demands, was divorced. ${ }^{73}$

This does not mean, however, that the Katangese company system was able by such means to produce stable family structures. Far from reducing family size to the 'two child' standard promoted by Mwana Shaba (above), the average Gécamines household (including adults) grew from 3.7 people in 1962 to 4 in 1967 and 6 by the end of the 1980 s. ${ }^{74}$ Company policies designed to promote nuclear families by the provision of maternal and welfare services in practice incentivised workers to have more children. Despite its best efforts, Gécamines was not able to exclude extended family members from its mine cités and, while direct evidence is inherently hard to obtain, it seems likely that at least some children registered under the company system were not the progeny of both the husband and his 'official' wife. Dibwe dia Mwembu indeed suggests that the prosperity of (mostly male) Gecamines' employees gave them the ability to 'keep' second wives in non-mine areas, unrecognised by the company and unable to access its social services. A new Zairian marriage code of 1987 decreed that children from illegitimate marriages should have the same access to

71 'Le mari est le représentant de l'entreprise dans sa famille. ... Alors que l'homme travaille, la femme, exclue au début du monde moderne du travail, s'occupe du ménage.' Dibwe dia Mwembu, Les Conditions dans la Vie, p. 26.

72 Dibwe dia Mwembu, Bana Shaba, p. 128.

73 Cited in Dibwe dia Mwembu, Bana Shaba, pp. 129-30.

74 Dibwe dia Mwembu, Bana Shaba, p. 145. 
services as their legitimate counterparts. As a result, companies were obliged to provide benefits to mineworkers' children from any and all marriages, for example schooling and medical care. This created a distinct intra-familial inequality, since second wives were still not entitled to company services. ${ }^{75}$

The new marriage code sought to shore up male authority in Zairian marriage in other ways, for example by placing the financial management of both spouses' assets in the hands of the husband. It also prohibited polygamy, in line with earlier (colonial) legislation proclaiming the sanctity of monogamous marriage. ${ }^{76}$ Dibwe dia Mwembu demonstrates, however, that the new code unintentionally strengthened polygamous families: he cites a case in which a man, married to his first wife in 1981, took a second wife when the first became sterile after giving birth to two children. Having had five further children with his second wife, rations obtained from Gécamines for all seven children were in practice shared across both households. This actually strengthened the status within the marriage of the second wife, while for many first wives their family life was destabilised. Dibwe dia Mwembu puts it thus: 'We are still witnessing (since the colonial period) the resistance of African manners, deeply rooted in the Congolese spirit in the face of modern laws in matrimonial matters' ${ }^{77}$ Alternatively, it might be argued that polygamy has in urban Katanga shown itself to be a modern practice in its ability to adapt to and work around a radically altered system of residence, work and economic incentives.

This body of research thus demonstrated that both Zambian and Katangese Copperbelt women were excluded from direct representation by the companies that relied on them to reproduce their husbands' labour, but they reacted to that exclusion in contrasting ways. That difference, while not preventing the considerable agency of Katangese women, did help reinforce the notion of Gécamines as an effective totalitarian regime and its ubiquitous characterisation as the father and mother of its workers and the description by interviewees of themselves as 'children of the company'. ${ }^{78}$ While today many former Zambian mineworkers and their family members characterise ZCCM

75 Dibwe dia Mwembu, Bana Shaba, p. 119.

76 Dibwe dia Mwembu, Bana Shaba, pp. 138-9.

77 Dibwe dia Mwembu, Bana Shaba, pp. 139-41.

78 Rubbers, Le Paternalisme. Interviews: Gaston Mutiti, Likasi, 4 June 2018; Pami wa Kasongo. 
as a company that cared for its workers, this familial analogy is not one that arises in interviews or wider popular discourse: it was rather a company on which mine families themselves made demands.

\section{Women's Work in the Post-Colonial Copperbelt}

While the historiography of late colonial and post-colonial Copperbelt women varies considerably, studies of both Zambia and Haut-Katanga tend to treat wage labour (gendered as male) and non-waged income as separate spheres and - despite the social history turn - continued to focus on mine areas rather than the wider urban Copperbelt society to which they were inextricably linked (Chapter 3). In practice, households earned a range of income types, which were certainly valued in different ways: mine companies paid cash wages to (mostly male) employees, but also provided food (consistently in Haut-Katanga, intermittently in Zambia) and a wide range of services and subsidies ranging from housing to free primary education to leisure activities. Households in general and women in particular grew foodstuffs not provided by companies, but women also earned cash by selling harvested produce to mine companies and to their neighbours. They also traded clothes and other manufactured items and sold sewn and knitted items that they often learned to make in company-run social centres. Notwithstanding the different orientations of the social history literature on Zambia (women's work as labour) and Katanga (women's work in the Gécamines family), their socio-economic and familial activities were similar to the extent that most women, unsurprisingly, juggled the double burden of domestic and non-domestic work.

The ubiquity of women's work challenges the observations of some analysts. Powdermaker, as noted, found agricultural cultivation among women in mining communities to be largely non-existent or in decline, but archival evidence and interviews suggest its ubiquity. Cultivation was banned by UMHK in the yards of workers' houses to prevent mosquitoes and, in any case, most yards were too small to allow anything but the smallest garden. Elsewhere in the mine towns it was, however, common to cultivate unoccupied land to supplement wages or to sell in the market or to neighbours. ${ }^{79}$ Daniel Henk found in

79 Interviews: Marie Jeanne Ngoy Mwamba and Valérienne Ngoy Mudimbi, both Likasi, 9 June 2018. 
the late 1980s that, while small plots had been cultivated by women in the 1950s, they were not now common because of dependence on formal wages. ${ }^{80}$ It is noteworthy that Henk's informants were themselves married male mineworkers, not their wives. Our interviewees suggest that, while farming may have briefly been less common among Katangese mineworkers' wives in the 1960s and 1970s, agriculture and trading in farmed produce was a widespread activity among women in Mufulira, Likasi and the wider urban Copperbelt, with much of the farming taking place in nearby rural and peri-urban areas where land was simply 'found' or leased from village chiefs on a quasi-sharecropping basis. ${ }^{81}$ Dibwe dia Mwembu, while stressing that women had always contributed to household economies, dates the increasing adoption of 'marginal' activities such as farming and trading to the economic difficulties from the mid-to-late 1970s onwards. ${ }^{82}$ While many interviewees did indeed start farming in earnest in response to decreasing real wages and increasingly precarious employment (see Chapter 8), many others had sought to farm in town from the time of their arrival and most of this activity was carried out by women. Kathbert Nchema, who grew up in Kitwe in the 1960s, recalls:

Most of the people in Kitwe had [farms].... Coming from a [rural] background where my parents enjoyed farming, we never saw any difference. From these gardens we were able to grow sweet potatoes, maize and other crops and we would even take the grain to the grinding mill and get mealie meal. In most cases people were not getting a lot of money [from employment] to sustain themselves and their families. Therefore, as a way of improving their livelihood, ladies usually, had to go in the gardens to fetch firewood because some people would not even manage to buy charcoal. ${ }^{83}$

Although Victoria Mwelwa remembers the distribution of food rations in Kitwe in the 1950s, she nonetheless grew crops 'on a free land - land which was unoccupied ... and earned extra income which helped us especially when the salary for my husband [was] delayed'. ${ }^{84}$

80 Daniel W. Henk, 'Kazi ya Shaba: choice, continuity, and social change in an industrial community of southern Zaire', unpublished $\mathrm{PhD}$ thesis, University of Florida (1988), p. 475.

81 Interviews: Nathan Mwamba, Mufulira, 7 July 2018; François Batabata Nsenga.

82 Dibwe dia Mwembu, Bana Shaba, pp. 132-3.

83 Kathbert Nchema interview, 9 July 2018. ${ }^{84}$ Victoria Mwelwa interview. 
Having initially described his mother as 'just a housewife', Simon Bwalya then explained that in the 1970s she 'was industrious and contributed to the family by selling munkoyo [a fermented maize drink]'. ${ }^{85}$ Boston Mwenya's 'housewife' mother equally bought vegetables wholesale from an Asian-owned store in Luanshya and resold them in a local market. ${ }^{86}$ Juliana Sakala arrived in Mufulira in 1979 and immediately started gardening 'to supplement the salaries we got to meet our family needs'. ${ }^{87}$ Farming was not the only means by which women earned money. In the 1970s and 1980s, Dorothy Musisha traded clothes in a business that involved periodic visits (conducted with groups of 'fellow women') to South Africa, Rhodesia/Zimbabwe and Malawi. She also visited Luapula Province to buy fish that she would then sell on the Copperbelt. ${ }^{88}$ André Kabinda Kasengo's job on Congolese railways (SNCC/Z) enabled his wife to travel to towns along the line of rail, selling clothing and other items and bringing back oil to sell in Likasi. ${ }^{89}$ Dieudonné Kalenga's wife converted the homemaking skills she learnt at the foyer social to make money doing sewing jobs for neighbours. ${ }^{90}$ Ana Chilufya, as well as farming maize, cassava and groundnuts for consumption and sale, travelled back and forth to her home area of Kawambwa on buses and lorries, bringing clothes from town to sell and buying foodstuffs which she then sold in the Mufulira council-run market. With the income, 'I used it to educate our children and supplement my husband's monthly salary'. ${ }^{91}$ Women's earnings were often earmarked for specific purposes and many interviewees used them to pay school fees. ${ }^{92}$

By the 1980s, many women were also doing salaried work. Gécamines, for example, had 1,744 female employees in 1979, just under 5 per cent of a workforce of $35,818 . .^{93}$ By 1988, women accounted for 10 per cent of its salaried staff or 'cadres'. ${ }^{94}$ As well as nurses, teachers and clerical workers, a significant number of these

\footnotetext{
85 Simon Bwalya interview. 86 Boston Mwenya interview.

87 Juliana Sakala interview.

88 Interview, Dorothy Musisha, Mufulira, 12 July 2018.

89 Interview, André Kabinda Kasengo, Likasi, 4 June 2018.

90 Dieudonné Kalenga interview. 91 Ana Chilufya interview.

92 Primary school was free for the children of Gécamines workers and, in many cases, for those of ZCCM, but secondary school was commonly paid for by workers themselves.

93 African Studies Centre, Leiden, Gécamines Annual Report 1979.

94 Dibwe dia Mwembu, Bana Shaba, p. 138.
} 
women were employed in the social centres that continued to train women in household skills and became social workers intervening in 'problem families', the subject to which we now turn.

\section{Post-Independence Social Welfare: Continuity and Change ${ }^{95}$}

In independent Zambia and Zaire, companies continued to provide extensive social services to their employees. In Haut-Katanga, social provision encompassed schooling and health care, as well as youth and women's centres, leisure services, company stores, maintenance and sanitation teams and policing common to both Copperbelt regions. In 1973, Gécamines' social services department ran fourteen social centres, eight girls' centres and twelve entertainment centres, alongside youth clubs and sports arenas. ${ }^{96}$ In 1975 , the company provided 42,649 free primary places for the children of its employees. ${ }^{97}$

While social intervention was, in the colonial period, predicated on the assumption that the supposed paternalistic 'customs' of rural African societies would be displaced by urban modernisation, postindependence social workers, mostly recruited from Copperbelt societies and many themselves the children of mineworkers, rejected such a characterisation in interviews. They rather identified ways in which 'custom', albeit in reconstructed forms, was an everyday part of urban life. They did, however, believe there were right and wrong ways to live in town and explained how and why they intervened in the family lives of employees to ensure their notion of social order. Social workers were strongly invested in the principle that companies should care for their workers and families and that this required intervention in family life to see that a worker's dependents were well cared for. Social workers saw their job as preventing divorce or separation in order to ensure that children were raised by a married couple. The motivation was, as retired senior social worker Mark Masumbuko suggests, 'to put harmony into the township: the most important thing was that miners, when they came home, they should find a habitable situation'. ${ }^{98}$

95 An extended analysis of the issues explored in this section can be found in Larmer and Taylor, 'The Decolonisation of Community Development', in Larmer et al., Across the Copperbelt.

96 African Studies Centre, Leiden, Gécamines Annual Report 1973.

97 African Studies Centre, Leiden, Gécamines Annual Report 1975.

98 Interview, Mark Masumbuko, Kitwe, 4 July 2019. 
Masumbuko linked this to the broader social peace of mining settlements:

If a miner knocked off, and he didn't find the wife [had] already prepared food, that would arise into talking. Or, if the wife was not at home, without telling the husband ... that would create problems. Or the miner himself knocks off, goes for a beer before getting home, he goes home drunk, that would create a problem. So, noise would start, and we would get involved. ${ }^{99}$

His former colleague Victor Chishala confirmed: 'A happy marriage will make the breadwinner perform his duties successfully'. ${ }^{100}$ Most Zambian social workers utilised similar explanations of their work that linked domestic content to an effective workplace.

Social welfare officers regularly investigated family disputes. Intervention was commonly prompted by a wife's complaint to a social worker - or, in Haut-Katanga, the chef de cité - that she was not receiving sufficient funds from her husband's wage to provide for the family. This might be because he was drinking too much alcohol or keeping another woman or even a second family. In a few cases husbands brought complaints about their wives for failing to maintain their households or drinking too much. A personnel officer could contact a social worker to investigate if an underperforming worker had domestic difficulties. ${ }^{101}$ Social workers arranged informal meetings with wives and husbands, discussed difficulties and obtained from them pledges about their future conduct: husbands might have to agree to hand a specific share of their wage to their wife. When spouses failed to agree what their problem was, social workers might contact their neighbours to ascertain what was causing conflict. Ultimately, backed by the company's authority as employer and landlord, part or even all the husband's salary could be directly paid to his wife to ensure the family was maintained. ${ }^{102}$

In both parts of the Copperbelt, company-run women's centres provided adult education. Women were trained in managing the household budget, something that supposedly ensured domestic harmony and prevented spousal conflict. ${ }^{103}$ Implicit in such training was still

\footnotetext{
99 Mark Masumbuko interview.

100 Interview, Victor Chishala, Kitwe, 6 July 2019.

101 Interview, Joseph Tumba Mwenzu, Mufulira, 11 July 2019.

102 Mark Masumbuko interview.

103 Josephine Lukwesa interview; Mark Masumbuko interview.
} 
a sharp distinction in the socialisation of young women in town compared with rural areas, both in the necessary skill set and in the shift from instruction by older female relatives to educated female trainers. ${ }^{104}$ These centres also continued to instruct women in domestic tasks: cooking, tailoring, cleaning the family home and raising children. ${ }^{105}$ Thérèse Kyola worked in a foyer social in Likasi from the 1960s until the 1990s: initially trained by white women to teach knitting, cooking and childcare, she went on to instruct the wives of railway workers to do some of these tasks:

At the end of the training, the learners tasted the recipe of the day and brought the leftovers for their spouses back to their respective homes. There were also days devoted to how to clean a house: the walls and the windows. There were also days devoted to unplanned visits to workers' homes, to assess the degree of mastery and the application of lessons learned. ${ }^{106}$

For Kyola, this training helped both men and women live up to the ideal gender roles previously advanced in Mwana Shaba: 'At the time, a good wife stood out through her good deeds: obedience, respect and submission to her husband. A good husband is one who knows how to listen to his wife. He cannot give me a course of action to follow and ignore mine'. ${ }^{107}$

During the late 1960s and 1970s, such training acquired a new purpose, that is, to generate income. Whereas male wages were initially characterised as sufficient to raise a family, it was increasingly recognised that women's earnings were an important source of income to the household and to the woman in particular. Women who received such training recall the skills they acquired with considerable pride. ${ }^{108} \mathrm{By}$ the 1980s, such training was understood as primarily for 'income generation', to the extent that its earlier, essentially 'domestic' role had been largely forgotten by interviewees.

Women's centres, some witnesses recall, also provided opportunities for unofficial forms of socialisation and the sharing of advice among women: one asserted that women were taught how to space their children without the use of contraception, which was not widely available. ${ }^{109}$ By the late 1980s 'women's rights' had in Zambia become part of some training courses. This did not mean that wives should not

104 Mark Masumbuko interview. 105 Ibid. 106 Thérèse Kyola interview.

107 Ibid. 108 Interview, Astrid Musumbi, Likasi, 6 August 2019.

109 Mark Masumbuko interview. 
obey their husbands, but efforts were made to help educated women assert their right to paid employment as a positive contribution to the household and to balance their health against giving birth to children. ${ }^{110}$

Custom, seen by late colonial observers to be a rigid barrier to effective adjustment to 'modern' life, proved to be flexible and responsive to the realities of urban living. Mine township residents adjusted to and managed potential differences in custom as the influence of the village diminished. Initiation ceremonies of children into adulthood took place either on brief visits to the village or in a reinvented urban form that 'was part of life in town'. ${ }^{111}$ Similarly, inter-ethnic marriages had become common: for Victor Chishala, his ability to counsel 'intertribal' couples was aided by his own upbringing as the child of an ethnically mixed Copperbelt marriage. ${ }^{112}$ Joseph Tumba Menzu describes a 'fusing' of marital customs: an implicit choice was made about which customs would be 'performed', without social conflict arising. Links to rural areas were declining and people were developing 'mixed customs'. ${ }^{113}$ While they did not pose the existential challenges to family life feared by many late colonial observers, they could certainly be the focus of marital and familial conflict.

As noted above, polygamy was ostensibly incompatible with company provision of housing and support: as Mark Masumbuko put it, if a man had more than one wife, 'you marry outside the system of the mines' ${ }^{114}$ Yet it is clear that polygamy continued to be practised in Haut-Katanga across and outside the company system in the ways described by Dibwe dia Mwembu. In Zambia, ZCCM would only intervene if polygamy led to conflict in the mine township. ${ }^{115}$ A second wife could not inherit her husband's pension and other benefits on his death. While social workers sought to safeguard widows' inheritance rights and ensure that they received the payment due after a husband's death in service, this could be undermined, as Ferguson noted for Zambia, by mineworkers' desire to pay benefits to their extended kin as well as or instead of their nuclear family. ${ }^{116}$

\footnotetext{
110 Josephine Lukwesa interview. 111 Mark Masumbuko interview.

112 Victor Chishala interview.

113 Joseph Tumba Menzu interview, 11 July 2019.

114 Mark Masumbuko interview.

115 Interview, Leonard Chola, Kitwe, 4 July 2019.

116 Ferguson, Expectations of Modernity.
} 
Across the Copperbelt, bereaved families had to leave their company house once all benefits had been paid: the remit of social intervention ran only to the termination of employment and there remained an entirely unrealistic assumption that surviving family members would 'return' to their rural areas. ${ }^{117}$

Unsurprisingly, the sustained intervention by companies into the marriages and households of their workers brought about neither an ideal modern urban family nor resolved ongoing conflicts over the relationship between wage and household labour, child-rearing and obligations towards individual family and kinship networks. The continuing provision of elaborate systems of social intervention attests less to the benevolence of company and state officials and more to their continuing anxiety over the disruptive effects of social conflict in mine communities. When Ferguson conducted his research in the late 1980s, marital relations were still beset by conflicts over the distribution of scarce resources between the wives and children of Copperbelt workers and their extended kin. Wives in multi-ethnic marriages were anxious about 'retiring' to their husband's village for fear of poisoning or witchcraft. Copperbelt residents still sought an ideal marriage based on 'modern' notions such as romance, fidelity and partnership, while experiencing the tensions arising from familial conflict and financial hardship. ${ }^{118}$ Henk tellingly found that, while many of his informants - male mineworkers in Kolwezi - had made inter-ethnic marriages, they nonetheless regarded such marriages as problematic and a cause of high divorce rates. Variations in what might previously have been termed 'custom' were now characterised as ethnic differences in the 'mentality' of wives regarding dowry and the role of the extended family. ${ }^{119}$ The idealised future urban marriage that was to have resulted from effective social intervention had, in a context of economic decline, become a thing of the past, associated with the steady jobs and company generosity of the golden age.

Research on the twenty-first-century Copperbelt indicates that the virtual collapse of the company system has, with the loss of the norm of male waged labour (a norm, it should be noted, only available to

117 Leonard Chola interview.

118 Ferguson, Expectations of Modernity, pp. 175-6.

119 Henk, 'Kazi ya Shaba', pp. 423-5, p. 516. 
a minority of actual Copperbelt residents), reconstructed gender relations in new ways. As Bobby Kabamba puts it:

Not so many people are working. Those who are living alright are those who are doing fine on the land ... . in most cases, what I have observed is that women are looking after men. They are paying for school children through the use of markets and business and so forth. ${ }^{120}$

Researchers and interviewees alike identify the growing importance of women breadwinners, but disagree about whether this is raising the status of women or imposing on them a typical 'double burden' of entrepreneurship alongside household management. ${ }^{121}$ The loss of formal employment is equally associated with a crisis of masculinity in which the inability of ex-workers to attract a wife and/or provide for their families is counterposed to a recent past in which marriage could be formed on a romantic and not a material basis. ${ }^{122}$

\section{Conclusion}

While understandings of gendered relations and the urban Copperbelt family have altered dramatically in the last sixty years, one thing has remained constant: actually existing relationships have been unstable and often conflictual. This has generated anxieties - among officials, chiefly authorities, social scientists, religious leaders, welfare officers and residents themselves - that faulty marital and familial relations, resulting variously from the sinful temptations of town life, incorrect adaptation to Western modernity or the injustices and inequalities of urban life, needed to be addressed by official intervention in the private lives of Copperbelt residents. Comparison has been drawn between such real relationships and idealised family types associated either with the recent past and/or the imminent future: a normative 'pre-colonial'

120 Bobby Jackson Kabamba interview.

121 For the former, see Alice Evans, "Women Can Do What Men Can Do": The Causes and Consequences of Growing Flexibility in Gender Divisions of Labour in Kitwe, Zambia', Journal of Southern African Studies, 40, 5 (2014), pp. 981-98. For the latter, see Patience Mususa, 'Contesting Illegality', pp. 185-208.

122 Benjamin Rubbers, 'Claiming Workers' Rights', pp. 329-44. For the centrality of gender in artisanal mining in Katanga see Jeroen Cuvelier, 'Men, mines and masculinities: the lives and practices of artisanal miners in Lwambo (Katanga province, DR Congo)', unpublished PhD thesis, University of Ghent (2011). 
rural patriarchy, or a modern nuclear urban family, providing clear gender divisions between productive and reproductive roles and enabling the culturally appropriate education and socialisation of children.

If we accept that family life and relationships have always been unstable and prone to conflict as a result of tensions between women and men and between older and younger generations, over the division of labour and of wealth, conflicts in which custom has been constantly invoked and continually challenged, and in which many participants assumed past family life was always more stable, then it is possible to reconsider the ways in which the gathering and dissemination of knowledge about the apparent transformation of gender relations in Copperbelt societies both reflected and shaped those relationships. Certainly, the increased adoption of wage labour, residence in mine company houses and the mixing of peoples with different ideas about sexual and social relations was perceived by most observers and experienced by many Copperbelt residents as a process of profound dislocating change, though not necessarily a singular or self-evident transition from a traditional to a modern way of doing things.

Social scientists at different times observed social and marital conflict arising from practices deemed by religious and political authorities as incompatible with modern urban life and argued they were dying out, or would soon do so. Respondents sometimes agreed about the impossibility of polygamy in the mine township, or the incompatibility of custom with inter-ethnic marriage, but polygamy, inter-ethnic marriage and other customary practices continued to be practised in town in different forms, without the dissonance between 'tradition' and 'modernity' ever being resolved. All this took place amid continuing social conflict, instability and the breakdown of some marriages, not because of an impending transition to, nor as the aftermath of, a stable urban social order, but rather as central features of a perpetually unstable urban reality in which evolving socio-cultural practices variously regarded as 'traditional', 'modern' or 'mixed' - rubbed uneasily alongside each other without ever being resolved. All the time, women, like men, worked - as housewives, farmers and traders selling their labour and putting to use skills learned in the 'traditional' sector or for the 'modern' household in creative and unpredictable ways. 